\title{
PROBLEMS AND PROGRESS IN NATURE CONSERVATION IN RHODESIA
}

\author{
G F T CHILD
}

\author{
Director \\ Department of National Parks and \\ Wild Life Management, \\ Causeway \\ Salisbury \\ Rhodesia
}

\section{Introduction}

The conflicting emotions generated around the aesthetic qualities of wildlife and its pragmatic use as a resource are a feature of human societies stretching into antiquity. On the one hand it has been, and remains, the subject of much folklore and art in societies extending from the Stone Age to the Technological Age. On the other, hunting for the necessities of life, and more recently for recreation, goes very deep into the history of the human race.

The first national park was constituted just over 100 years ago, but this was a modern rationalisation of the well established custom of setting aside protected areas for such purposes as religious sanctuaries or exclusive hunting preserves. This phenomenon is found in the traditions of a wide variety of cultures and seems to be motivated by a wish to preserve areas in a natural state.

It follows that wildlife and wild areas have an intrinsic human appeal, forming important components of the national heritage and deserving careful protection by the community. Such protection is prompted by human need and its primary justification is the satisfaction of that need. This does not imply a disregard for the rigid conservation of the wild qualities upon which the sustained value of the resource is dependent, if it is to satisfy human demand now and in the future. The demand is likely to escalate with intensified urbanisation and must be accommodated as a means of raising rural productivity and combatting the urban maladjustment syndrome.

The economic benefits are difficult to quantify, but are considerable and probably far outweigh any visible earnings from the resource. This fact is not widely appreciated but even at the present level of knowledge, the provision of public outdoor recreational facilities, often through the agency of nature conservation, makes very good sense in practical, and human, terms. 
This argument justifies nature conservation in all its forms, at least as much as the somewhat theoretical and perhaps overstated cliches so often put forward by proponents of nature conservation, such as the preservation of nature being a responsibility of man to his fellow-living organisms. It is also necessary to recognise that nature conservation, especially in areas set aside exclusively for this purpose, is a form of land use, dependent on certain basic criteria. It is worth repeating that the long-term success of all human endeavour in an organised society depends on the reconciliation of the essential requirements of three sets of factors linked in the chain of survival. Reduced to their most generalised forms these are the socio-political, ecological and economic parameters upon which the fabric of society and Government ultimately depends.

Accepting this truism, it is relevant to recall that both the sociopolitical and economic links in this chain were forged by man and can be modified by him, while the ecological link depends on the laws of nature which cannot be amended. If evidence is needed in support of this it is to be found in the many socio-political and two major economic systems practised on a world-wide basis, within a framework of universally applicable ecological principles. Social systems evolved from the need for the division of labour essential to an integrated society in the face of ecological challenges, while economics is that branch of human ecology in which man's energy relations are reduced to precise units of barter in equating this division of labour. The growth and spread of human populations and the evolution of complex societies, however, have elevated the importance of these two sets of factors in the survival of developed communities, although this importance cannot transcend that of their remaining within the sustainable energy flow of their environments. Cognizance of the limitations imposed on any form of land use by these three parameters is very germane to any argument for, or against, the conservation of nature.

This paper seeks to outline achievements in the nature conservation field in Rhodesia before proceeding to examine problems to be faced in the immediate and longer term future. In so doing, some of the properties of the resource and the legal and administrative machinery for its protection and rationalised use under local conditions, both on public and privately owned land, are considered. Any such review must, of necessity, be rather superficial and over-generalised, but emphasis is directed to indicating how administration and management are being developed to meet the three sets of limiting factors described above.

\section{The resource and its administration}

Wildlife is a source of Food and other useful products in almost every country of the world and to this may be added its value, and that of wild areas, based on their innate human appeal. These values must increase, 
rather than diminish, in the face of expanding human populations if the quality of life, as we understand it, is to be maintained for all our people in the medium and long terms. Failure to recognise this is to deny the actual and potential value of the resource in raising rural productivity and the importance of outdoor recreation to the community, especially the urban sector.

Land use planning in several densely peopled and highly developed regions of the world emphasises the importance of wild life and open space in the lives of their citizens and it is pertinent to reflect upon the ubiquitous exploitation of wild populations for food or useful products.

The African vertebrate fauna, in its richness and diversity, surpasses that on any other continent. It is a unique and highly marketable commodity that can and should be exploited for the benefit of the people of the country in which it occurs, but this use must be skilful if the resource is to retain its marketability. It must be recognised that the resource is based on living systems with characteristic biological limitations that cannot be exceeded, that it is frequently highly charged with emotion and that, in many instances, its marketability is dependent on the maintenance of acceptable aesthetic standards.

It is now appropriate to examine the status of the wildlife resource in Rhodesia and the machinery that has been evolved to protect it. The country has a wildlife resource comparable with that in any equivalent area in Africa and is well placed to profit from it. This results from the country's geographical position, its inherent ecological diversity and generally high productivity, and from the accidents of history.

Rhodesia was settled by pasturalists relatively late in the history of the Continent and the only species known to have been exterminated by modern man, the square lipped rhinoceros, Ceratotherium simum, has been successfully re-established from relict populations in Zululand. The second accident of history that has favoured wildlife in general, and conservation areas in particular, has been their proximity and accessibility to sophisticated local and international markets, without their being overrun by the various forces of the technological age. Finally, there is the role of successive administrations in the conservation of wildlife in what is, today, Rhodesia. Early tribal settlement was generally well adjusted to the environment, or at worst, had relatively little lasting influence on long-term productivity, and even the warlike Matabele had at least one royal hunting preserve in the vicinity of the present Wankie National Park. A Western form of government was introduced to Rhodesia in 1890 and by 1902 Cecil John Rhodes had created two areas, one in the Matopos and one at Inyanga, which, in all but name, met the then accepted criteria of national parks. With the passage of time and the evolution of concepts, further sanctuary areas were proclaimed and culminated in the present Parks and Wild Life* Estate extending over

*Legal requirements demand the use of "Wild Life" as two words where this refers to legislation or titles emanating from it. 
some $10 \%$ of the country. Similarly, laws have been evolved to protect the resource outside this Estate and to integrate its use with other forms of land use.

The administration of the resource, in all its forms, is entrusted to the Department of National Parks and Wild Life Management, which is answerable to the Minister of Lands and Natural Resources. This Department is a scientifically orientated land-use agency with a wide range of responsibilities which extend well beyond the ecological field into such related disciplines as tourism, food production and land-use planning. For descriptive purposes it is convenient to differentiate between its functions within the Estate and those associated with the protection of the resource and its proper use elsewhere, although both are closely related.

\section{Parks and Wild Life Estate}

The Parks and Wild Life Estate of some 4524400 ha includes six land-use categories (Fig. 1), which offer protection to most higher animals and plants with an effective geographical range extending into Rhodesia. All the characteristic veld types, with a wide distribution in the country, with the exception of Parinari mobola "parkland", are also represented.

The Estate is only partially developed for visitor use which could be increased five-fold without serious impact on its natural qualities or a lowering of the present high aesthetic standards, although it will require a modification in the patterns of permissible use, especially in some Safari Areas. Future human demand is difficult to gauge, depending as it does on many variables, but it is anticipated from the evidence available, that this level of development will be needed for optimum public satisfaction by the last decade of this century. Predictions beyond the year 2000 become progressively more theoretical, but the present Estate should be able to satisfy domestic and foreign needs for some considerable time afterwards, without too much impact on its natural qualities, provided the use remains in sympathy with these qualities.

Some 180000 domestic and foreign visitors paid to enter the Estate in 1975 , but as entry to many of its components is free, it is probable that over 500000 people used the Estate, which is the cornerstone of the tourist industry valued at $c a$ Rhod. $\$ 50 \mathrm{~m}$ ( 1 Rhod. $\$=\mathrm{R} 1,25=\mathrm{US}$ \$1,55)p.a.

Each unit of the Estate is administered in terms of an appropriate section of the Parks and Wild Life Act (1975) and the regulations flowing from it, but is, or will be, subject to a specific Policy Document. These documents. approved by the Minister upon the recommendation of an advisory board, define the objectives of management and utilization for each area or part thereof. They are the basis of defined long-term development plans for visitor and administrative facilities and of plans 


\section{Rhodesia}

\section{PARKS AND WILD LIFE ESTATE}

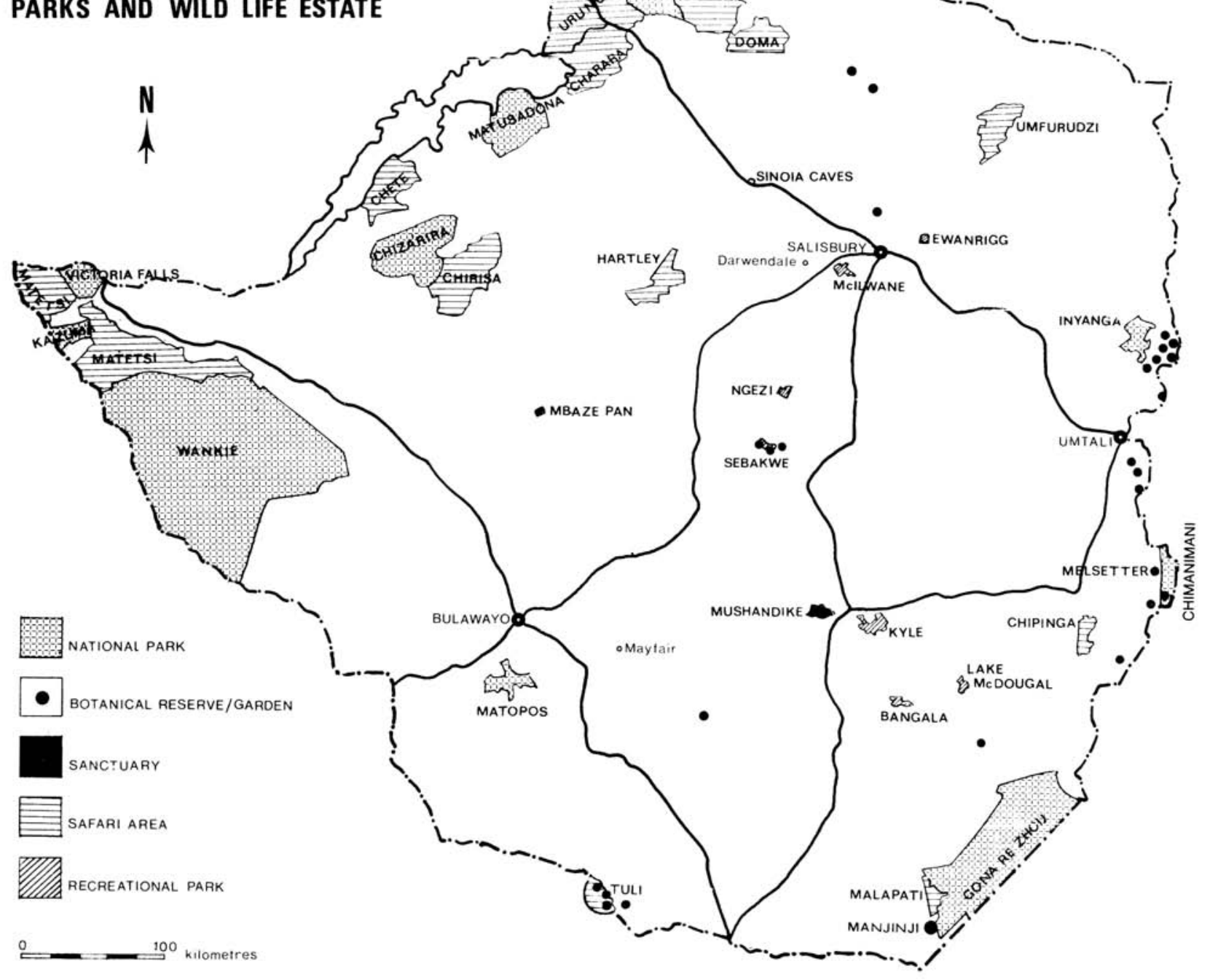


TABLE 1

Main characteristics of Rhodesia's National Parks

\begin{tabular}{|c|c|c|c|c|c|c|c|c|c|c|c|c|c|c|c|c|c|c|c|c|c|c|c|c|c|c|c|c|}
\hline \multirow[b]{2}{*}{$\begin{array}{l}\text { National } \\
\text { Park }\end{array}$} & \multirow[b]{2}{*}{$\begin{array}{c}\text { Area } \\
\text { ha }\end{array}$} & \multicolumn{8}{|c|}{ Main natural attributes } & \multicolumn{5}{|c|}{ Zonation for use } & \multicolumn{5}{|c|}{$\begin{array}{l}\text { Main visitor } \\
\text { activities now }\end{array}$} & \multicolumn{9}{|c|}{ Development } \\
\hline & & 鄫 & 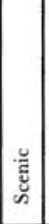 & 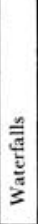 & 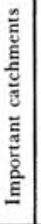 & 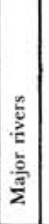 & 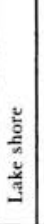 & 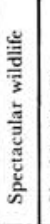 & 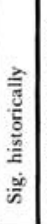 & 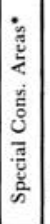 & 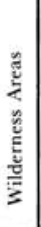 & 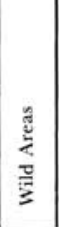 & 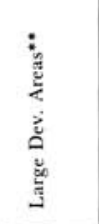 & 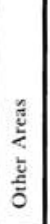 & 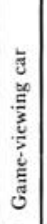 & 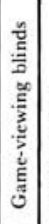 & 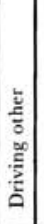 & 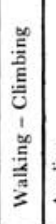 & . & 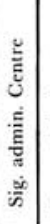 & 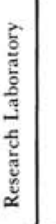 & 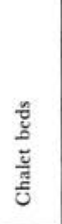 & 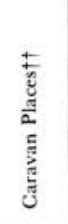 & 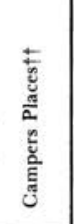 & 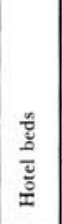 & 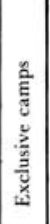 & 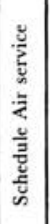 & 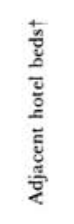 \\
\hline Chimanimani & 17100 & $\mathrm{x}$ & $\mathrm{x}$ & & $\mathrm{x}$ & & & & & & $\mathrm{x}$ & & $0(1)$ & & & & & $\mathrm{x}$ & & & & 28 & & 5 & & & & 72 \\
\hline Chizarira & 191000 & $\mathrm{x}$ & $\mathrm{x}$ & & $\mathrm{x}$ & & & $\mathrm{x}$ & & & $\mathrm{x}$ & $\mathrm{x}$ & $0(1)$ & & $\mathrm{x}$ & & & & & $\mathrm{x}$ & $\mathrm{x}$ & & & & & $\mathrm{x}$ & & \\
\hline Gonarezhou & 496400 & & & & & $\mathrm{x}$ & & $\mathrm{x}$ & & & $\mathrm{x}$ & $\mathrm{x}$ & $0(3)$ & & $\mathrm{x}$ & & & $\mathrm{x}$ & $\mathrm{x}$ & $\mathrm{x}$ & $\mathrm{x}$ & 15 & & 23 & & $\mathrm{x}$ & & 60 \\
\hline Inyanga & 29637 & $\mathrm{x}$ & $\mathrm{x}$ & $\mathrm{x}$ & $\mathrm{x}$ & & & & $\mathrm{x}$ & & $\mathrm{x}$ & $\mathrm{x}$ & $3(2)$ & $\mathrm{x}$ & & & $\mathrm{x}$ & $\mathrm{x}$ & $\mathrm{x}$ & $\mathrm{x}$ & $\mathrm{x}$ & 220 & 50 & 26 & 38 & $\mathrm{x}$ & & 331 \\
\hline Mtarazi & 2495 & $\mathrm{x}$ & $\mathrm{x}$ & $\mathrm{x}$ & & & & & & & & $\mathrm{x}$ & $0(1)$ & & & & & $\mathrm{x}$ & & & & & & & & & & \\
\hline Kazuma Pan & 31290 & & & & & & & $\mathrm{x}$ & & & & $\mathrm{x}$ & $0(1)$ & & $\mathrm{x}$ & & & & & & + & & & & & & & \\
\hline Mana Pools & 220000 & $\mathrm{x}$ & $\mathrm{x}$ & & & $\mathrm{x}$ & & $\mathrm{x}$ & & & & $\mathrm{x}$ & $1(1)$ & & $\mathrm{x}$ & & & & $\mathrm{x}$ & $\mathrm{x}$ & $\mathrm{x}$ & 26 & & 55 & 14 & $\mathrm{x}$ & & \\
\hline Matopos & 44200 & & $\mathrm{x}$ & & $\mathrm{x}$ & & & $\mathrm{x}$ & $\mathrm{x}$ & $\mathrm{x}$ & $\mathrm{x}$ & $\mathrm{x}$ & $1(2)$ & $\mathrm{x}$ & $\mathrm{x}$ & $\mathrm{x}$ & $\mathrm{x}$ & $\mathrm{x}$ & $\mathrm{x}$ & $\mathrm{x}$ & $\mathrm{x}$ & 106 & 21 & 87 & & & & 30 \\
\hline Matusadona & 137000 & $\mathrm{x}$ & $\mathrm{x}$ & & & & $\mathrm{x}$ & $\mathrm{x}$ & & & $\mathrm{x}$ & $\mathrm{x}$ & $0(2)$ & & $\mathrm{x}$ & & & $\mathrm{x}$ & & $\mathrm{x}$ & $\mathrm{x}$ & & & 24 & & $\mathrm{x}$ & & \\
\hline Vic. Falls & 57300 & & & $\mathrm{x}$ & & $\mathrm{x}$ & & $\mathrm{x}$ & $\mathrm{x}$ & & $\mathrm{x}$ & $\mathrm{x}$ & $1(1)$ & & $\mathrm{x}$ & & & $\mathrm{x}$ & $\mathrm{x}$ & $\mathrm{x}$ & + & 100 & & & & & $\mathrm{x}$ & 936 \\
\hline Wankie & 1462000 & & & & & & & $\mathrm{x}$ & & $\mathrm{x}$ & $\mathrm{x}$ & $x$ & $3(3)$ & & $\mathrm{x}$ & $\mathrm{x}$ & & $\mathrm{x}$ & & $\mathrm{x}$ & $\mathrm{x}$ & 282 & 50 & 24 & & $\mathrm{x}$ & $\mathrm{x}$ & 354 \\
\hline Total & 2688422 & 6 & 7 & 3 & 4 & 3 & 1 & 8 & 3 & 2 & 8 & 10 & $9(18)$ & & 8 & 2 & 2 & 7 & 6 & 8 & 7 & 777 & 121 & 244 & 52 & 6 & 2 & 1783 \\
\hline
\end{tabular}

*Further Special Conservation Areas will be set aside as this becomes necessary.

**Indicates present and projected number of large tourist camps.

+ Part of Matetsi complex for Research purposes.

† Hotels within $50 \mathrm{~km}$ of a National Park and heavily dependent on it.

$\dagger+$ Each caravan and camping place accommodates up to six persons. 
for the monitoring and management of the biological resources. These plans, more especially the mangement plans, are more flexible than their parent Policy Documents and can be altered according to a defined procedure. In this way the authority of Parliament is decentralised, by formalised stages, to the officer on the ground, who enjoys considerable autonomy within prescribed limits, without this adversely affecting the continuity of Departmental effort with time and changes in personnel.

It is now appropriate to describe the various land classes in the Parks and Wild Life Estate in an attempt to illustrate their integrated function, although it is acknowledged that in so doing the picture is oversimplified and the attributes of each area are grossly understated. Eleven National Parks (Table 1), total ca 2688422 ha and enjoy the highest conservation and protective status of any land in Rhodesia.

The next categories of protected areas, are Botanical Reserves, Botanical Gardens and Sanctuaries. These areas are set aside primarily for the conservation of individual species populations, or for the conservation of particular biotic communities, or for the propagation of, mainly, indigenous plants. Apart from the Botanical Gardens, they have many attributes in common with National Parks, although due to their small size, it is seldom possible to adopt a holistic approach to the management of their ecosystems. Areas enjoying this status are listed in Table 2 and 3 which also indicate their chief attractions and the fact that Botanical Reserves are sometimes superimposed on nature conservation areas with a lower status. A proportion of these areas is not included in the Parks and Wild Life Estate.

Safari Areas (Table 4) have replaced and extend the scope of the old Controlled Hunting Area concept in recognition of the fact that these large areas lend themselves to a whole range of outdoor activities besides hunting. The policy applied in each Safari Area varies according to the area's main attributes and the activities to be permitted and encouraged in it. In some, hunting will predominate, at least within the foreseeable future, while in others, hunting will be of minor importance or excluded altogether, and other forms of outdoor recreation such as hiking, game-viewing or angling may assume paramountcy, if they have not already done so, in the multi-use system which is being sought in each Safari Area. Even the present hunting areas are administered differently according to whether the rights are leased to a commercial firm or whether hunts are sold directly to individuals. The huntable species and the number of each offered as trophies in each hunting area in 1975 are given in Table 5 which also shows the success ratio attained by hunters. The Chewore, Sapi and Matetsi Safari Areas are destined for eventual elevation to National Park status.

There are also a number of Recreational Parks (Table 6), all but one of which are associated with large impoundments like Lake Kyle and Lake McIlwaine. Here natural features and the countrified atmosphere are preserved and protected, but a wider range of outdoor activities may 
TABLE 2

\section{Botanical Reserves and Gardens}

\begin{tabular}{|c|c|c|c|c|}
\hline Reserve & $\begin{array}{c}\text { Area } \\
\text { ha }\end{array}$ & 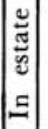 & Main Features & Comments \\
\hline Pioneer & 38 & $\mathrm{x}$ & $\begin{array}{l}\text { Fuchsia tree, Schotia brachy - } \\
\text { petala }\end{array}$ & $\begin{array}{l}\text { In Tuli Safari } \\
\text { Area }\end{array}$ \\
\hline Tolo River & 44 & $\mathrm{x}$ & Monkey thorn, Acacia galpinii & , \\
\hline South Camp & 26 & $\mathrm{x}$ & $\begin{array}{l}\text { Nyala tree, } \text { Xanthocercis } \\
\text { zambesiaca }\end{array}$ & , \\
\hline Chirinda & 949 & & Mountain Forest & In Forest Land \\
\hline Banti & 175 & & $\begin{array}{l}\text { Yellowwoods, Podocarpus } \\
\text { milanjianus }\end{array}$ & In Forest Land \\
\hline Stapleford & 212 & & Cyads, Encephalartos manikensis & In Forest Land \\
\hline Sebakwe I & 60 & $\mathrm{x}$ & Acacia karroo & $\begin{array}{l}\text { In Sebakwe } \\
\text { Recrational Park }\end{array}$ \\
\hline Sebakwe II & 165 & $\mathrm{x}$ & Great Dyke flora & $\begin{array}{l}\text { In Sebakwe } \\
\text { Recreational Park }\end{array}$ \\
\hline Sebakwe III & 53 & $\mathrm{x}$ & $\begin{array}{l}\text { Mountain "Acacia", Brachystegia } \\
\text { glaucescens }\end{array}$ & $\begin{array}{l}\text { In Sebakwe } \\
\text { Recreational Park }\end{array}$ \\
\hline Vumba & 201 & $\mathrm{x}$ & $\begin{array}{l}\text { Botanical garden, montane } \\
\text { forest }\end{array}$ & \\
\hline Chisekera & 94 & & $\begin{array}{l}\text { Hot springs, mangrove fern, } \\
\text { Acrostichum aureum }\end{array}$ & \\
\hline Miware & 34 & & Raphia palm, Raphia farinifera & \\
\hline Tingwa & 290 & & Raphia palm, Raphia farinifera & \\
\hline Mazoe & 8 & & $\begin{array}{l}\text { Mountain Acacia, Brachystegia } \\
\text { glaucescens }\end{array}$ & \\
\hline Bunga & 40 & $\mathrm{x}$ & Montane forest & \\
\hline Shashi & 4300 & & $\begin{array}{l}\text { Mulala palm, Hyphaene } \\
\text { benguellensis }\end{array}$ & \\
\hline Chingwarara & 256 & & Cycads, Encephalartos concinnus & \\
\hline Kubarakwawena & 2 & & Bamboo, Oxytenanthera abyssinica & \\
\hline Marishira & 2 & & Bamboo, Oxytenanthera abyssinica & \\
\hline Nyanzwe & 8 & & Low altitude evergreen forest & \\
\hline Pungwe Bridge & 14 & & Low altitude evergreen forest & \\
\hline Rumise & 39 & & Low altitude evergreen forest & \\
\hline $\begin{array}{l}\text { Tegwe } \\
\text { Haroni }\end{array}$ & $\begin{array}{r}4 \\
20\end{array}$ & & $\begin{array}{l}\text { Bamboo, Oxytenanthera abyssinica } \\
\text { Low altitude evergreen forest }\end{array}$ & \\
\hline Rusitu & 150 & & Low altitude evergreen forest & \\
\hline Ewanrigg & 286 & $\mathrm{x}$ & Botanical garden, miobo woodland & \\
\hline Salisbury & 67 & & Botanical garden, miombo woodland & \\
\hline Total & 7537 & 913 & & \\
\hline
\end{tabular}

*Of the 913 ha within the Parks and Wild Life Estate 527 ha comprise separate areas not included in other categories of the Estate. 
TABLE 3

Sanctuaries

\begin{tabular}{l|r|l}
\hline Sanctuary & Area ha & Main Attributes \\
\hline Melsetter & 1200 & $\begin{array}{l}\text { Protection relict eland population; protection catchment } \\
\text { area of town water supply; Bridalveil Falls. }\end{array}$ \\
\hline $\begin{array}{l}\text { Manjinji } \\
\text { magnificent }\end{array}$ & $\begin{array}{r}300 \\
\text { riverine }\end{array}$ & Bird sanctuary on ox-bow lake of Nuanetsi river with \\
\hline Mbaze & 40 & Bird sanctuary on ox-bow lake of Shangani river. \\
\hline Mushandike & 12900 & $\begin{array}{l}\text { Complexity of habitats; improving wildlife populations; } \\
\text { environmental education for primary school children; } \\
\text { ungulate grazing research. }\end{array}$ \\
\hline Total & 14440 & \multicolumn{2}{|l}{}
\end{tabular}

be allowed than is either possible or desirable in truly wild areas. Most are near urban complexes and are readily accessible to a large number of people. These parks are generally quite small and more of them will be needed as human populations expand and become more sophisticated. To this end it is policy to examine the recreation potential of each new large dam and two are now in the process of being included in Recreational Parks.

The Parks and Wild Life Estate provides an integrated system of outdoor recreational facilities catering for a range in human tastes and protecting natural values through the proper conservation of a spectrum of natural and semi-natural ecosystems and their elements. As noted, each area is the subject of its own policy, describing how the natural landscapes are to be protected and the aims sought from the management of the flora and fauna, but acknowledging that few, if any, areas in Rhodesia have escaped the modifying influences of modern man. The policy also provides guidelines for the development of the area and sets down the types and levels of utilization, either in the area as a whole or any part thereof, so as to protect the resource and the quality of experience offered to visitors. The latter is also facilitated through the zonation of permissible activities.

Zonation takes several forms, ranging from the exclusion of certain activities in specific areas to the more formal division of National Parks, and to a lesser extent other conservation areas, according to criteria which seem appropriate in the Rhodesian context. Special Conservation Areas are generally small and designed to protect especially sensitive biological features or for defined research purposes, and access to them 


\section{TABLE 4}

\section{Safari Areas}

\begin{tabular}{|c|c|c|}
\hline Safari area & Area ha & Present use and future plans \\
\hline Chete & 108100 & $\begin{array}{l}\text { Long term University Research; crocodile } \\
\text { research; hunting leased to one safari company. }\end{array}$ \\
\hline Hartley 'A' & 71597 & $\begin{array}{l}\text { Very limited hunting leased to hunters' } \\
\text { association; planned as future recreational area } \\
\text { for Salisbury and Midland towns. }\end{array}$ \\
\hline Urungwe & 288000 & $\begin{array}{l}\text { Hunting with individual hunts sold by } \\
\text { Government on tender basis - Angling. }\end{array}$ \\
\hline Chewore & 339000 & $\begin{array}{l}\text { As for Urungwe but destined for elevation to } \\
\text { National Park in due course. }\end{array}$ \\
\hline Sapi & 118000 & $\begin{array}{l}\text { Hunts sold at fixed price to members of the } \\
\text { hunting association; due for elevation to } \\
\text { National Park in due course. }\end{array}$ \\
\hline Tuli & 40400 & $\begin{array}{l}\text { Hunting with hunts sold by Government on } \\
\text { individual tender basis. }\end{array}$ \\
\hline Doma & 76400 & Limited hunting leased to hunters' association. \\
\hline Chipinga 'A' & 26100 & Limited hunting leased to hunters' association. \\
\hline Umfurundzi & 76000 & Limited hunting leased to hunters' association. \\
\hline Matetsi & 292000 & $\begin{array}{l}\text { Hunting leased to } 7 \text { safari companies holding } \\
\text { concessions, due for eventual elevation to } \\
\text { National Park status. Will then absorb two } \\
\text { Forest Reserves and will link Wankie and } \\
\text { Victoria Falls National Parks. }\end{array}$ \\
\hline Deka & 51000 & $\begin{array}{l}\text { Limited low intensity hunting mainly associated } \\
\text { with wilderness trails now under trial. }\end{array}$ \\
\hline Chirisa & 171300 & $\begin{array}{l}\text { Long term wildlife research; game-viewing; } \\
\text { protein production. }\end{array}$ \\
\hline Malapati & 16200 & $\begin{array}{l}\text { Adjunct to Gonarezhou National Park; } \\
\text { game-viewing wilderness area. }\end{array}$ \\
\hline Dande & 52300 & $\begin{array}{l}\text { Game-viewing or hunting in association with } \\
\text { protein production planned. }\end{array}$ \\
\hline Charara & 170000 & $\begin{array}{l}\text { Management for spectacular species, e.g. } \\
\text { elephant, lion, buffalo for game-viewing - } \\
\text { angling and water sports on Lake Kariba. }\end{array}$ \\
\hline Total & 1896397 & \\
\hline
\end{tabular}


TABLE 5

The main species that may have been hunted, and the quota, actual take-off and percentage success by Safari Areas and in

Rhodesia in 1975

*Urungwe and Nyakasanga combined from 1976

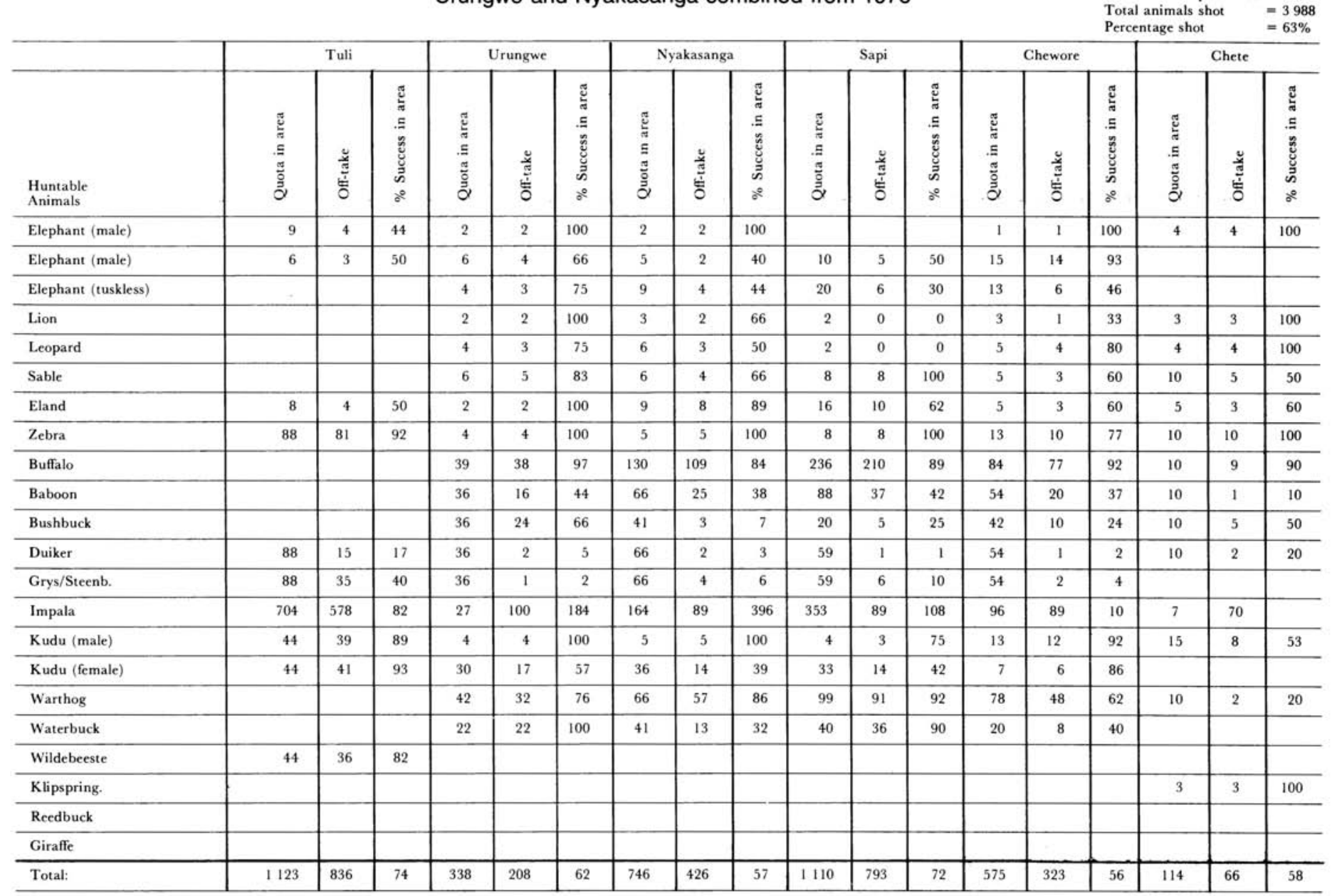


TABLE 1 (continued)

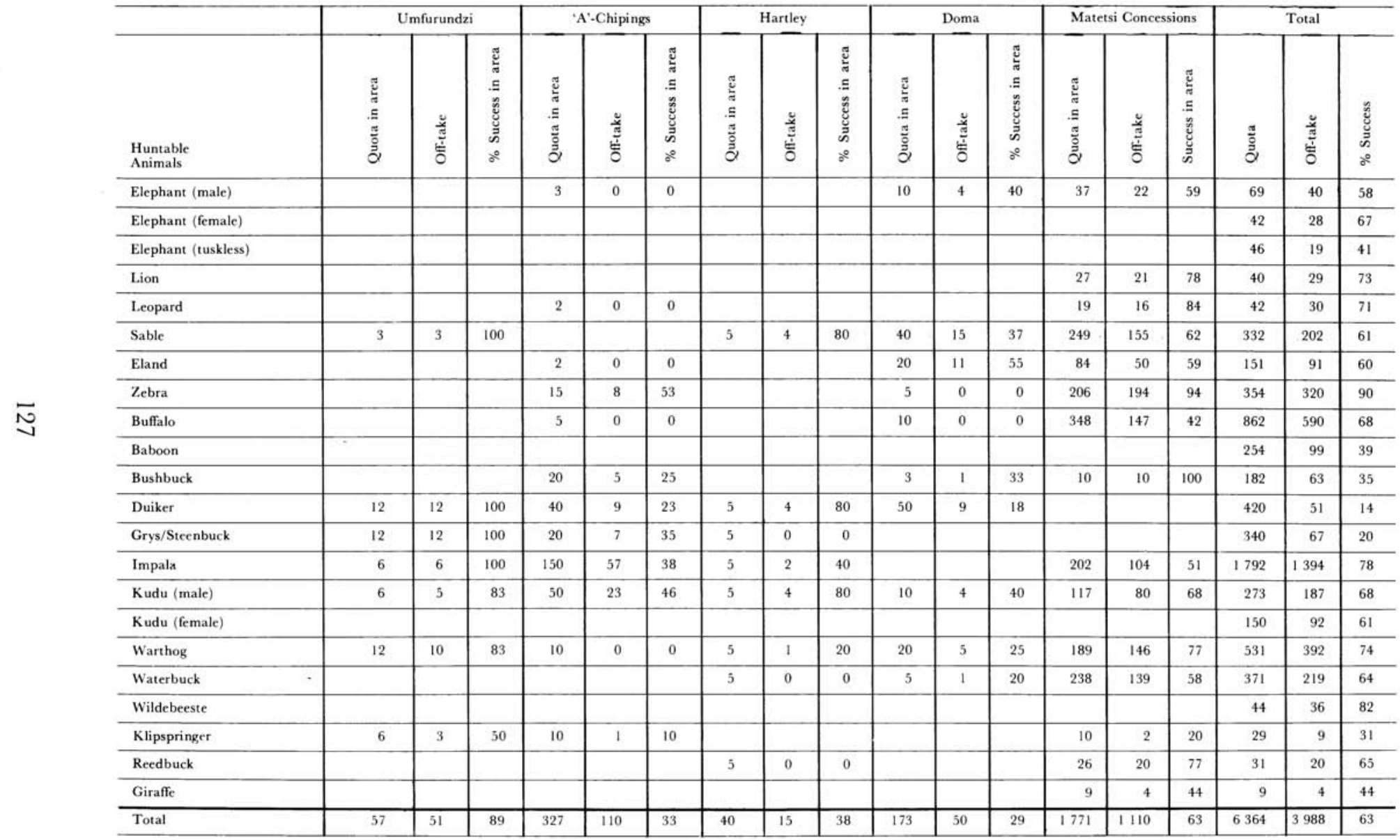


TABLE 6

Recreational Parks

\begin{tabular}{|c|c|c|c|}
\hline $\begin{array}{l}\text { Recreational } \\
\text { Park }\end{array}$ & $\begin{array}{c}\text { Area } \\
\text { ha }\end{array}$ & $\begin{array}{c}\text { Area } \\
\text { water ha }\end{array}$ & Main features and visitor activities \\
\hline Kyle & 16900 & 9105 & $\begin{array}{l}\text { Attractive impoundment with adjacent game park; } \\
\text { angling and other water orientated outdoor } \\
\text { recreation; commercial fishing; high quality } \\
\text { game-viewing; ungulate grazing research. }\end{array}$ \\
\hline Sinoia & 148 & 0 & Dolomite caves. \\
\hline McIlwaine & 6100 & 2630 & $\begin{array}{l}\text { Large impoundment near Salisbury with } \\
\text { adjacent game park; high intensity water } \\
\text { orientated outdoor recreation; commercial } \\
\text { fishing; fisheries and ornithological research } \\
\text { station. }\end{array}$ \\
\hline Ngezi & 5800 & 580 & $\begin{array}{l}\text { Medium-sized dam; Great Dyke; reasonable } \\
\text { game populations; quiet outdoor reacreation } \\
\text { based on widely spaced accommodation } \\
\text { amenities. }\end{array}$ \\
\hline Sebakwe & 2700 & 1518 & $\begin{array}{l}\text { Medium dam especially suited to yachting - } \\
\text { wall to be raised; Great Dyke; some angling; } \\
\text { commercial fishing. }\end{array}$ \\
\hline Bangala & 2.800 & 1133 & $\begin{array}{l}\text { Large dam with good recreational potential but } \\
\text { so far undeveloped. }\end{array}$ \\
\hline Manjirenji & 3501 & 2023 & $\begin{array}{l}\text { Large dam with good recreational potential but } \\
\text { so far undeveloped. }\end{array}$ \\
\hline Umzingwani & 1233 & 456 & $\begin{array}{l}\text { Near Bulawayo in densely populated Tribal } \\
\text { Area; some boating and angling but potential } \\
\text { needs to be developed. }\end{array}$ \\
\hline Total & 39182 & 17445 & \\
\hline
\end{tabular}

is strictly controlled. Limited numbers of people are allowed into Wilderness Areas, but visitors are permitted the greatest possible freedom of action commensurate with the declared policy for each such Area. It is not possible to generalise on how each Wilderness Area is to 
be used or on the ultimate level of development if any, as this is determined by local conditions. Suffice it to note that where buildings are essential for administrative or management purposes only, they will be extrememly primitive, and where vehicle access is necessary for staff or visitors, it will be on rudimentary tracks.

More people are permitted into a Wild Area at any given time, than could be allowed into a similar Wilderness Area, but their activities are more prescribed. Here development may include such amenities as roads, made-up paths and game-viewing blinds, augmented by appropriate interpretative material. Defined Development Areas cater for necessary staff facilities and visitor amenities and range in size from simple picnic sites through bush camps for visitors and scout outposts, to fairly large complexes with modern tourist accommodation and services. In spite of the obvious impact that large Development Areas have on their immediate environs, efforts are made to maintain their aesthetic appeal through attention to atmosphere and by limiting the number of visitors that may be accommodated at any one time to some 300 persons, even in the largest establishments.

This brief outline indicates the scope of the Estate both as a means of conserving nature and offering visitors an enjoyable experience. Recreational Parks provide for a relatively large number of people who are not necessarily seeking a high quality wilderness experience, thus relieving the pressure on other areas, while at the same time allowing urbanites, who are unaware of the pleasures and need for outdoor recreation, the opportunity of participating in it in aesthetically attractive surroundings. The need to attract people from the city into the countryside is not very apparent in Rhodesia at this time, but there are clear indications that it will become as important here as in more urbanised communities where generations of city dewellers have lost touch with the outdoors. It is planned that their use of Recreational Parks will motivate them to avail themselves of the whole range of activities available, within the Estate, and culminating in the use of remote and unspoiled wilderness.

Problems associated with the administration and protection of nature conservation areas in Rhodesia probably differ little, except in relative magnitude, from those found elsewhere, and fall into three main groups. The first stems from limitations on development and management imposed by available finance and hardly justifies further consideration here. The second derives from the management necessitated by past land use in the area of the park, or by the present and past use of areas adjacent to it. It is often necessary to cushion these impacts, and all too often, this management has to be directed at the effect, rather than at the cause, of ecological imbalance. This often leads to protracted action, or to the making of management decisions leading to measures that conflict with the concept of a truly natural ecosystem. Fire management and the control of wild fire; soil conservation works; the provision of artificial waterholes to render seasonal habitats suitable for year-round occupa- 
tion by animals or to supplement reduced river flow resulting from upstream impoundments; the control and manipulation of animal populations, and the elimination of feral alien plants are examples of such management objectives.

The third group of problems relates to human attitudes and is due to ignorance and thoughtlessness, or is motivated by personal gain and a disregard for the long-term welfare of the resource and its value to the community. There are also the public pressures which result from commendable, but ill-informed, sentiment. An analysis of these problems in Rhodesia suggests that ignorance, thoughtlessness and misguided sentiment are bound to occur, but can be greatly reduced through the provision of appropriate interpretative and public relations services. All personnel have a role to play in these fields, but until now, their joint efforts have lacked direction and impact in the absence of specialised guidance and it is hoped to alleviate this defect with the launching of an interpretative service within the Department.

A public relations effort is needed to counteract these forces and to engender a better public appreciation of park values through personal experience. Strict control over visitor activities, not only in the interests of their own safety, but also to ensure that the actions of a few do not destroy the pleasure of the majority, are obviously essential. It is desirable nevertheless, even in big game country, to permit visitors the best possible visual, tactile, olfactory and auditory stimulation from the natural environment. This is difficult while they are incarcerated in a motor vehicle. For this reason the Department has increased the number of game-viewing blinds and picnic sites in Wankie and elsewhere and has instituted walks, wilderness trails and horse-riding. Exclusive camps are being provided in some Parks where visitors will enjoy the exclusive use of the camp and the area around it on a weekly basis.

There is also the danger of over-use in the short-term at the expense of the future, resulting mainly from the provision of profit motivated services, especially where these are in the hands of a brash commercial operator. It is good business for a tour operator, for example, to provide the minimal experience in a park that his clients will tolerate before rushing them to the next attraction, thus keeping his staff and machines fully utilized. Fortunately there are few such operators in Rhodesia, where it has been possible to control both their number and their actions through a single agency conserving and marketing the product on which they depend.

Even more dangerous is the farmer or peasant who looks upon nature conservation areas as land that is vacant and into which he should be permitted to expand his own activities. Living in the outdoors, he has no idea of the real need for outdoor recreation amongst his urban cousins, and it is difficult to convince him otherwise, against a background of the personal gain he could derive from having the land. Rhodesia has tried for a number of years, and with some success, to create alternative 
values for conservation areas, which are readily understood by neighbouring rural people. Rights to cut thatching grass, sell curios, or benefit from the products of management have all been effective to some extent, although the provision of employment for this end, suggested by IUCN, has been less useful. This may relate to the fact that the level of employment would probably vary little, whether or not an area were deproclaimed, and because payment for labour is widespread, and is related to the job and not to the special status of the area.

\section{The resource outside the estate}

Rhodesia has a substantial wildlife resource outside the Parks and Wild Life Estate and landholders have a large measure of discretion over its use, tempered by the modulating influence of their local communities and of Central Government. The administration and exploitation of the resource, and the industry based on it, present many challenges which defy adequate or consistent treatment in this brief review.

The Parks and Wild Life Act (1975) recognises Royal Game (10 mammals, 40 birds and 1 reptile) and Specially Protected Indigenous Plants (48 species), whose protection remains the responsibility of Central Government. They enjoy a very high legal status which is illustrated by the fact that Royal Game may not be hunted without a permit, even in defence of property. Two sets of criteria are used to determine if a species requires such protection; its status in the wild in Rhodesia and the country's obligations to international conservation. The schedules listing these species are subject to constant review, but it is recognised that every additional species will tend to detract from the legal position they each enjoy, and that in many instances, the inclusion of a species is a measure of failure on the part of the conservation movement to safeguard it by other means.

In the case of the vast majority of species, it is accepted that landholders and landholder communities are better placed than anyone else to conserve their wildlife and that, without their co-operation, no amount of legal protection will ensure its survival. There are no blanket hunting seasons, although local communities may impose these on themselves through their conservation committee, which may also initiate the legal protection of animals and plants in the area of its jurisdiction. Central Government licence fees for hunting and fishing on private land have been abolished. Instead landholders are encouraged to profit from any activities they permit on their properties, or from any other use of the resource, so as to compound the aesthetic justification for preserving it and as one means of further diversifying and enhancing rural productivity within sustainable ecological limits and in harmony with other forms of land use.

This approach recognises the differing needs of the resource in time and space and provides the incentives to protect and use it wisely, 
without Central Government abrogating its ultimate responsibilities, as it retains the power to take unilateral action where this is necessary. It also retains close supervision over the commercial exploitation of wildlife and wildlife products, including their movement to and from the country. For example, while a landholder may usually decide whether an animal may be shot and by whom, and while he may dispose of the meat as he wishes, he may not sell a live animal or a trophy, without a permit. This provides the necessary statistics for co-ordinating the industry and a check against abuses, which are further curbed by monitoring the activities of trophy dealers and the cultivators of certain indigenous plants. In all cases the aim is to encourage legitimate trade and to discourage the abuse of the resource.

These measures are a logical progression from the legal framework evolved to meet the game ranching concept and, while the new legislation has been in force for less than a year, Government is cautiously optimistic of the results in general. As a consequence of the new Act, the role of the central administration has shifted still further from pure law enforcement into the extension field. This, and the recent upsurge in interest in wildlife among landholders is placing a strain on extension and research services, which are being confronted with a whole range of new demands, that is offset only slightly by the close co-operation of agricultural and wildlife extension officers.

Game ranching and fish farming were pioneered in Rhodesia in the early 1960s and suffered from over optimistic predictions and harvesting or marketing problems. These persist, but have become less formidable over the years, due to an increasing demand for protein and a growing realisation of the resources' complementary, rather than competitive, function in the rural economy. Opposition to commercial fishing by the angling fraternity has diminished in the light of research that has demonstrated the low level of competition between the two and the benefit to angling of controlled netting in artificial impoundments.

An optimised return is sought from the exploitation of the fish resource by angling and commercial means on a countrywide basis, and in individual waters including Lake Kariba, with the emphasis in any particular impoundment being determined, in part, by public demand. Rhodesia is unlikely to become self-sufficient in fish production, but there is a considerable potential for narrowing the gap between supply and demand. Market trends will continue to influence the production of both luxury and coarse fish, but recent developments in trout culture and the exploitation of the introduced Tanganyika sardine, Limnothrissa miodon, in Lake Kariba, together with a rising general interest in commercial fishing, suggest a definite trend towards reducing this gap.

Game ranching, as an industry producing protein and other useful products, has not developed into a viable form of regional land use, although it yields large quantities of protein and provides an additional source of income on a number of properties. Profitability rises where a 
proportion of the off-take is offered for recreational hunting. This hunting, together with that in National Forests, in certain Safari Areas and in a number of communally held Tribal Trust Lands, is the basis of a lucrative high-class safari industry. Agreements vary from area to area, but in most they result in a satisfactory return to the landowner. In concession areas in the Tribal Trust Lands, for example, the bulk of the meat goes to individual tribesmen, while the royalties for hunting accrue to the tribal authority for local development projects and, in this way, the value of the resource to the local people is enhanced without their being denied a traditional source of food.

There are three commercial crocodile rearing stations in Rhodesia which represent the type of specialised use of an individual species which it is policy to encourage. These highly profitable ventures still depend upon the controlled harvesting of wild-laid eggs and benefit the parent populations in that a proportion of the well grown progeny are returned to the wild under the supervision of the authorities. The dependence on wild populations is clearly a disadvantage and the breeding of Nile crocodiles, Crocodilus niloticus, in captivity is being investigated with encouraging results.

Wildlife may also conflict with legitimate human interests. A prize trophy under one set of conditions may become a stock or garden raider under others, and each situation must be resolved on its own merits. Here pragmatic considerations often weigh against the interests of individual wild animals in the interests of the fauna as a whole. Of particular concern are those occasions when wild dog, Lycaon pictus, is involved as this species, which cannot be tolerated in stock producing areas, has been reduced numerically throughout Rhodesia and is now poorly represented, even in large sanctuary areas. Hippo, Hippopotamus amphibius, is another species whose future is not assured outside the Parks and Wild Life Estate, although populations show optimistic trends within the Estate, particularly along the shores of Lake Kariba. On the other hand bush pig, Potamachoerus porcus, which is a very real problem to crop producers has remained numerous, in spite of the best efforts directed against it, and still occurs within a few kilometres of the cities of Gwelo and Salisbury.

The relationship between wildlife and the diseases of domestic stock remains a problem on occasions, although enlightened veterinary thinking and an improved understanding of the relationship between domestic stock, wildlife and disease organisms has placed it in better perspective. Nevertheless, the apparent involvement of buffalo in the foot-andmouth-disease syndrome has necessitated the elimination of this otherwise valuable species, where landholders have requested it, and it is accepted that its relocation on farms is inadvisable at this stage. Research, which is still in its infancy, is designed to explore the possibility of creating a foot-and-mouth disease free buffalo herd.

An analysis of the epidemiology of rabies in Rhodesia indicates that it 
is primarily an affliction of domestic dogs, but has spilled over into wild animals such as jackals which must now be controlled in outbreak areas. Examination of outbreaks of the disease in Botswana and adjacent parts of Rhodesia suggests that they are, in part at least, due to bad land management suppressing perennial grasses and favouring annuals in good rainfall years after a drought, thus setting the stage for rodent eruptions. These eruptions favour predators such as jackal whose numbers increase and whose populations are subject to stress and become highly susceptible to an epizootic, like rabies, after the rodent numbers crash.

Rodent eruptions can also lead to serious crop damage which prompts farmers to use powerful and long-lasting poisons in their control. While this drastic action may result in immediate relief, its impact on the ecosystem has not been examined and it is feared that such overreaction, leading to the deaths of many predators and other wild animals, may be compounding the problem for farmers in the future. For this reason they have been discouraged from using powerful and indiscriminate toxins and have been assured of a supply of acceptable rodenticides.

The quelea problem is another situation where control must be directed at the effect rather than the cause, as it is a problem that may emanate from outside the country and one which also appears to have its root cause in patterns of land management. These birds may disperse many hundreds of kilometres from their breeding concentrations, which are favoured by suppressed pastures leading to a good annual grass growth and heavy seed burden in years of good rainfall. An increase in winter cereal production then enhances their chances of survival at a season when numerically strong populations would be entering a period of critical food stress. Control of quelea is reasonably simple and can be relatively harmless to other aspects of the ecosystem, but is an example of an ongoing problem which could be solved only by international co-operation and a general improvement in land-use practices.

In advocating the use of wildlife, Central Government has sought the co-operation of the private sector in the implementation of a generally acceptable approach to the conservation of the resource and its continued use for the benefit of all citizens. This will inevitably lead to conflicts between the preservationist and the practical land manager that can only be resolved by a realistic appreciation of the place of wildlife in any given landuse policy. Acceptance of this principle and of the fact that wildlife covers a wide range of animals and plants, is leading to a willingness among many landholders to conserve and use certain wild populations that do not conflict unduly with their primary livelihood. In some cases where wildlife-use began as an ancillary facet of a man's livelihood, it has assumed dominance thus demonstrating its value in large parts of the country. 


\section{Discussion}

Although Rhodesia, in common with most states in Africa, has many seemingly insurmountable land-use problems which must be resolved if ecological deterioration is to be halted and the trend reversed, it has an enviable record in the field of resource conservation. This has been achieved through the blending of public and private endeavour in a joint venture based on mutual confidence and in which the Natural Resources Board has performed a key role.

In the case of the wildlife resource, Central Government remains responsible for the administration, management and development of the Parks and Wild Life Estate as an integrated entity, with individual elements also harmonising with the needs of regional development. Government is also responsible for co-ordinating and controlling the wildlife industry as a whole in the national interest, but in so doing has sought a large measure of decentralisation of responsibility for the resource outside the Estate. This is achieved through the Natural Resources Board and its Intensive Conservation Area Committees, which blanket most of the alienated land in the country. Both the board and its conservation committees are manned by public-spirited individuals with a deep personal commitment to the conservation ethic. Thus the community is largely responsible for the administration of its wildlife and individual members stand to benefit from its wise use within the limits laid down by their local and national representatives in the conservation movement, as well as in Government.

A similar hierarchy of control based on grass roots representation is also possible in the communally occupied Tribal Trust Lands, but requires further encouragement before it will attain the sophisticated effectiveness prevailing in many areas of alienated land. This is a primary challenge in some $42 \%$ of the country, but already the people of some Tribal Trust Lands are benefiting significantly from the controlled use of their wildlife.

The mechanisms outlined above provide a basis for the socio-political acceptance of the value of the Parks and Wild Life Estate and the wildlife resource in general. It also provides the means whereby these assets can, and do, profit all levels of the national and rural economies, and, by and large, the conservation of nature is in sympathy with the ecological capacity of the land. Thus provision is made for the proper long-term conservation of the resource within the essential parameters of sustainable human endeavour.

One major challenge has already been mentioned and others arise due to an expanding human population, anticipating improved living standards from an impoverished environment. The conservation of the wildlife resource, like other natural resources, faces many difficulties, especially in the short term during the essential transition from a predominantly rurally orientated community to one which must become 
more urbanised. This transition is likely to reach a critical peak during the next two or three decades and during this time the conservation movement must become more firmly rooted and have even wider acceptance if the next and following generations are to enjoy a quality of life comparable with our present standards.

Land use will intensify, even in the nature conservation field, and many concepts will require careful scrutiny in order to ensure that maximum human benefit is derived from the wildlife resource without sacrificing its intrinsic properties. There is a need to plan now for the future, while at the same time acknowledging that outdoor recreational facilities will come under close examination be proponents of conflicting forms of land use, especially during the interim period mentioned above.

Action must be based on an optimistic but realistic approach, and must recognise that the tree of minor controversies is but a part of the forest of major significance to the survival of a concept which is itself but a $\operatorname{cog}$ in the machine of ecological stability upon which the future of the human race depends. There is every likelihood that a scientifically based, ecologically orientated land use agency will resolve ecological problems in isolation, but to achieve lasting results this must be achieved within the limits of acceptable socio-political and economic parameters. This necessitates an acceptance, at all levels of a disciplined community, of the significance of nature conservation in economic terms. In many cases this is essentially a marketing problem; a case of selling the concept and selling the product.

The second major challenge facing nature conservation in Rhodesia, and many other African nations, is the need to plan for the future while satisfying the present. Land must be set aside now for a future tourist market, but should not seem te remain idle while this market develops. With some $10 \%$ of the country earmarked for nature conservation, the basic real estate needed to satisfy future needs is catered for, at least into the first decade of the twenty-first Century, and the problem is to use this land in the interim without compromising its resource values.

Long term planning of the Parks and Wild Life Estate is in hand in order to rationalise development as the need arises and funds permit. In the meantime several areas destined for elevation to National Park status are being managed as Safari Areas in an attempt to derive optimum financial benefit from them at their present level of development. The products of the management of animal populations are being made to yield valuable protein or live animals for the restocking of land where a species or species is locally extinct, and a careful look is being taken at the profitability of visitor usage.

Every enlightened nation is fully justified in conserving representative samples of its wild renewable resources, but this justification is amplified where such conservation is of direct human value to the citizens of the country. The potential is considerable and use will vary with time, according to prevailing public demand. This will require some flexibility 
of policy and attitudes and is subject to skilful manipulation through appropriate public relations efforts, but present administrators would be failing in their duty if they permitted current circumstances to undermine the fundamental assets of which they are the temporary custodians.

\section{Acknowledgements}

For assistance with the preparation of the manuscript for this paper I should like to thank Mrs Colleen Hughs who drew the map, Miss Maria De Souza who typed the fair copy and Mr A W J Wood, who assembled the statistics. Mr. R I G Attwell and the late Mr F A Burke kindly read and commented on the initial draft of the manuscript. 